\title{
Hardness Analysis of Epoxy Composite Reinforced with Glass Fiber Compared to Nettle Fibers
}

\author{
IGP Agus Suryawan ${ }^{1}$, NPG Suardana ${ }^{2 *}$, IN Suprapta Winaya ${ }^{3}$ and IWB Suyasa ${ }^{4}$ \\ ${ }^{1}$ Study Program of Doctoral Engineering Science, Faculty of Engineering, Udayana University \\ ${ }^{1,2.3}$ Study Program of Mechanical Engineering, Faculty of Engineering,Udayana University \\ ${ }^{4}$ Study Program of chemistry, Faculty of Mathematic and Sains,Udayana University \\ *npgsuardana@unud.ac.id
}

\begin{abstract}
The purpose of this study is to compare the hardness of glass fiber reinforced composite materials with the hardness of netted fiber-reinforced composite materials. Glass fiber is a commercial fiber that has been used in various industries while nettle fiber is a natural fiber that is more environmentally friendly. Composite material has several advantages, namely the form that can be adjusted, high strength, lightweight and resistant to corrosion. Nettle plants are plants that have strong fibers in the bark. In this study, nettle composites were made with variations in the weight fractions of 10\%,15\%, and 20\%. Hardness testing used the Shore D Durometer. The results of the hardness value of glass fiber composites with weight fractions of $10 \%, 15 \%$, and $20 \%$ are 82.4 Shore D, 84.5 Shore D, and 86.5 Shore D, show an increase in stable hardness because the glass fiber factor is already commercial, the fiber strength is evenly distributed. The hardness values of nettle fiber composites with fractions of $10 \%, 15 \%$, and $20 \%$ are 81.6 Shore D, 85 Shore D, and 86.6 Shore D, the hardness value of each nettle composite increases with the addition of fiber weight fraction but is unstable due to the strength factor of each nettle single fiber uneven. Furthermore, with the right treatment, nettle fiber can replace glass fiber.
\end{abstract}

Index Terms - composite, stinging nettle, glass fiber and hardness.

\section{INTRODUCTION}

$\mathrm{F}$ ibrous composite continues to be developed and researched to be an alternative material as a metal substitute. This is because composites have relatively stronger and lighter fiber properties compared to metals. Composite is a combination of two or more materials that have different phases into a new material that has better properties than before [1].

The nature of composites is greatly influenced by the nature and the distribution of its constituent elements. In general, the most often fibers used as reinforcement are artificial fibers such as fiberglass, verre, and carbon [2]. Bamboo as an activated carbon can be made of composite material [3]. This artificial fiber has an advantage in strength but is expensive and not environmentally friendly. Therefore, natural fibers from the nettle plants are developed to make fibers that are cheaper and environmentally friendly.

Nettle is a plant that has fiber on the bark and is suitable for cultivation in Indonesia [4]. Special treatment is needed to produce fibers that have a smooth surface and high tensile strength. Nettle plants are annual plants with the potential to live in fertile fields for one year or more [5].

The objective of this research is to find out the hardness of composite materials with natural fiber reinforcement from nettle plants compared to the reinforcement of fiberglass in the form of artificial fibers.

\section{RESEARCH PROCEDURE}

The materials used in this research and testing are as follows; Epoxy resin, hardener, nettle fiber, and glass fiber. Material for fiber treatment; distilled water and $\mathrm{NaOH}$. Additional material is glycerin to coat the mold so that the resulting composite material does not stick to the mold. The tools used in research and testing are digital scales, measuring cups, composite molds made of glass, calipers, pressure beams, specimen testers cutting machine, 


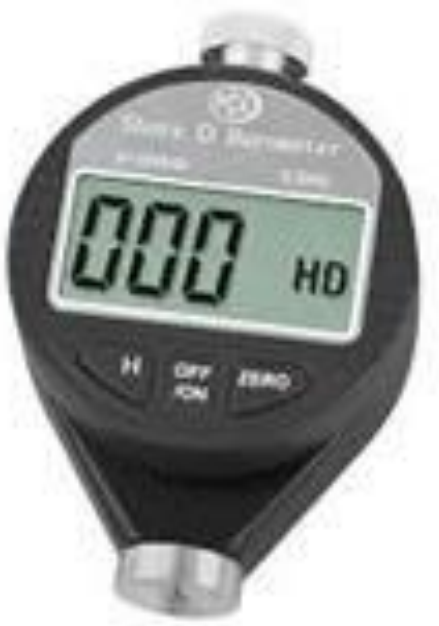

Fig. 1. Shore D Hardness Tester

The steps in this research were preparing the jet fiber through the process of fiber retting or fiber separation from the nettle plant, then measuring the fiber weight according to the fiber weight fraction, then mixing the fibers, resin, and hardener then stirring and pouring it into the mold, and waiting until the specimen is dry. The process of printing glass fiber through the same process with the printing process of nettle fibers.

The assumptions set in this study include; Nettle fibers used have uniform physical characteristics, especially the age of nettle plants by limiting plant height to at least $50 \mathrm{~cm}$, the age of nettle plants are obtained [6]. The orientation of the fibers used is random direction and it is assumed that the distribution of fibers in the composite is evenly distributed. The nettle fiber used comes from the nettle plant found in Candi Kuning Village, Baturiti District, Tabanan, Bali.

Material hardness is material resistance to penetration. The principle used to measure Shore D hardness is based on the strength of needle resistance that penetrates the test material under known spring loads. The results of this test are used to compare the hardness of composite materials. Hardness test materials are designed as Figure 2. Hardness testing using shore $\mathrm{D}$ is more effective and easier to do because this test can be easily removed and can give an idea of the mechanical properties of a material [7]. The measurement is done at one point of material and repeated at another point at a distance of $1 \mathrm{~cm}$. In one data sample, 5 points were taken.

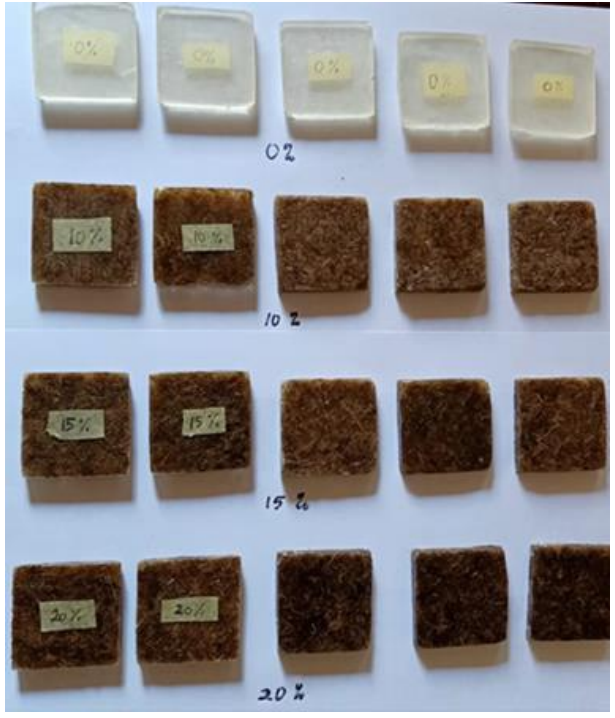

Fig.2. Hardness Test Specimen

III. RESULTS OF THE STUDY

Data from the test results with Durometer Shore D are tabulated in Table I and Table II.

TABLE I

THE HARDNESS OF NETTLE FIBER COMPOSITE

\begin{tabular}{|c|c|c|c|c|c|c|}
\hline $\begin{array}{c}\text { Teight point } \\
\text { fraction }\end{array}$ & $\mathbf{1}$ & $\mathbf{2}$ & $\mathbf{3}$ & $\mathbf{4}$ & $\mathbf{5}$ & $\begin{array}{c}\text { Average } \\
\text { value }\end{array}$ \\
\hline Resin & 71,0 & 69,0 & 72,0 & 69,5 & 72,0 & 70,7 \\
\hline $10 \%$ & 81,0 & 81,5 & 80,0 & 81,0 & 84,5 & 81,6 \\
\hline $15 \%$ & 82,0 & 85,0 & 85,5 & 84,5 & 88,0 & 85,0 \\
\hline $20 \%$ & 87,0 & 88,5 & 86,5 & 84,5 & 86,5 & 86,6 \\
\hline
\end{tabular}

TABLE II

THE HARDNESS OF GLASS FIBER COMPOSITE

\begin{tabular}{|c|c|c|c|c|c|c|}
\hline $\begin{array}{l}\text { Test point } \\
\text { fraction }\end{array}$ & $\mathbf{1}$ & $\mathbf{2}$ & $\mathbf{3}$ & $\mathbf{4}$ & $\mathbf{5}$ & $\begin{array}{c}\text { Average } \\
\text { value }\end{array}$ \\
\hline Resin & 71,0 & 69,0 & 72,0 & 69,5 & 72,0 & 70,7 \\
\hline $10 \%$ & 78,0 & 82,5 & 83,0 & 83,0 & 85,5 & 82,4 \\
\hline $15 \%$ & 86,5 & 84,0 & 85,5 & 83,0 & 83,5 & 84,5 \\
\hline $20 \%$ & 86,0 & 86,0 & 85,0 & 88,0 & 87,5 & 86,5 \\
\hline
\end{tabular}


It can be seen in Table I the hardness of nettle fiber composites has increased hardness with the addition of fiber in epoxy from $0 \%, 10 \%, 15 \%$, and $20 \%$ with hardness values of 70.7, 81.6, 85.0 and 86.6 Shore D.

It can be seen in Table II the hardness of nettle fiber composites has increased hardness with the addition of fiber in the composite mixture of $0 \%, 10 \%, 15 \%$, and $20 \%$ with hardness values of 70.7, 82.4, 84.5, and 86.5 Shore D.

From the data in Table I and Table II we can see the comparison of the hardness of the nettle and fiberglass composites. In the fraction of $10 \%$ fiberglass composites have a higher hardness than nettle fiber composites, in the $15 \%$ fraction nettle fibers composites are harder than glass fiber composites, and $20 \%$ of nettle fibers and glass fibers have almost the same hardness.

The hardness test results using the Shore Durometer can be seen in Figure 4. The hardness of the resin matrix is 70.7 \pm 1.40 Shore D. The hardness of nettle composites with $10 \%$ fiber weight fraction is $81.6 \pm 1.71$ Shore $\mathrm{D}$; with a $15 \%$ fiber weight fraction, the hardness is $84.4 \pm 1.39$ Shore $\mathrm{D}$; and with a fiber weight fraction of $20 \%$, the hardness is $86.6 \pm$ 1.43 Shore D. The hardness of the nettle fiber composite increases with increasing fiber weight fraction. Fiber is very influential on the hardness of composite materials, where the higher the strength of the fiber the higher the material hardness.

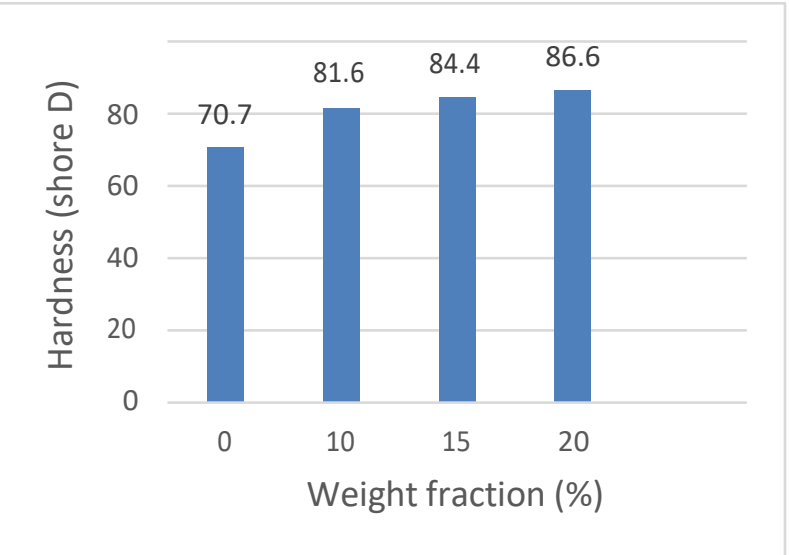

Fig. 4. Correlation between fiber weight fraction and hardness in nettle composites

In line with Khalidi's research [8] n epoxy particle composites, the more the number and the larger the diameter of the reinforcing particles the higher the hardness of the composite particles. Research by Kasim [9] on polypropylene composites reinforced with pineapple leaf fibers with fractions $(30,40,50,60$, and 70$) \%$ by weight of fiber, the fiber length of $100 \mathrm{~mm}$. Produced by compression printing technique at a pressure of $3.5 \mathrm{MPa}$ for 7 minutes, at a temperature of $1900 \mathrm{C}$ with directional fiber orientation.
The fiber is soaked in a $5 \% \mathrm{NaOH}$ solution for 1 hour at room temperature. Composite hardness was measured using the Shore Durometer "D" type ASTM D1957. The maximum hardness at $70 \%$ by weight of pineapple fiber is 65.38 Shore$\mathrm{D}$ and a density of $1.002 \mathrm{~g} / \mathrm{cm}^{3}$. Adding fiber up to $30 \%$ increases hardness by only $0.53 \%$.

In the nettle-composite study, the addition of fiber from $0 \%$ to $10 \%$ increased the hardness by $13.33 \%$, where the increase was quite large. Whereas the hardness of composites with the addition of $10 \%$ fiber to $20 \%$ by weight of nettle fiber increased only $5.77 \%$, where the increase was small. Hardness is very closely related to surface properties. With the presence of nettle fibers on the surface, it will be able to hold the identity through the composite material, which nettle fibers are known to have greater strength than epoxy.

As a comparison, glass fiber reinforced composites are made as shown in Figure 5, where glass fibers are commercially sold fibers.

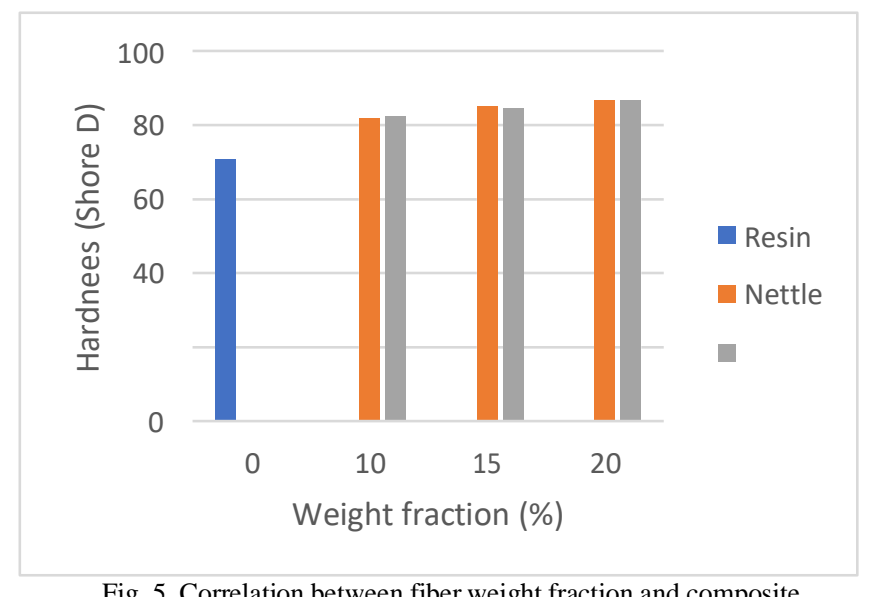

Fig. 5. Correlation between fiber weight fraction and composite hardness

Hardness of composites at $10 \%$ fraction, glass composites have more hardness compared to nettle composites. Whereas in the fraction of $15 \%$ nettle composites have more hardness compared to glass composites. But in the fraction of $20 \%$ glass and nettle composites have almost the same hardness. When conducting hardness testing with the Shore D test, the addition of fibers to the nettle and glass fiber composites has an impact on the increased hardness of the material which is caused when adding fiber, the bond between the fibers increases with the addition of heavy fractions. In the technical journal [10] it was obtained the hardness of epoxy composite polymer material with palm shell fiber reinforcement with $40 \%$ fiber weight fraction with a hardness value of 77.33 Shore D and $60 \%$ with a hardness value of 79 Shore D, an increase in the hardness of the composite material by adding weight on the fraction of fiber. 


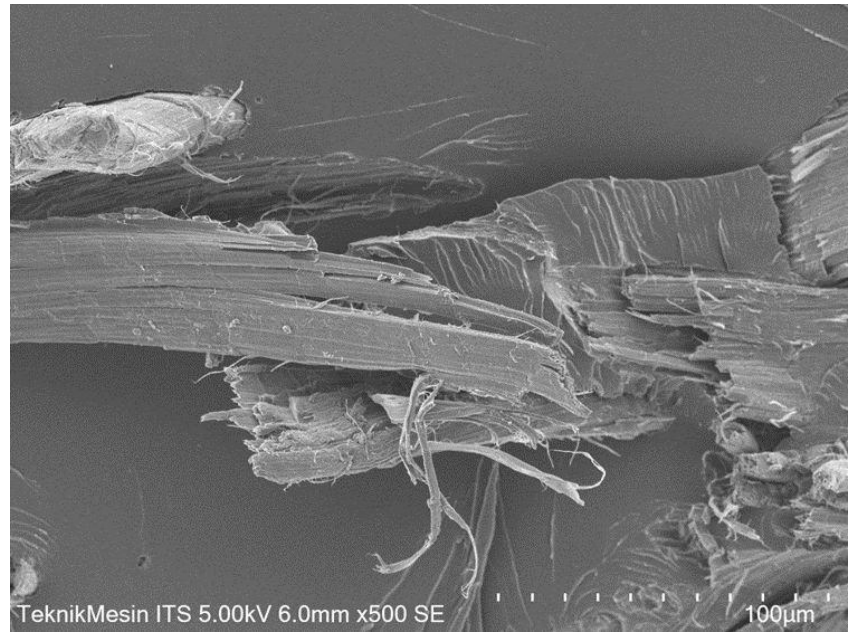

Fig. 6. Nettle composite fracture with $10 \%$ of fiber

Based on the results of SEM composite observations with a ratio of $10 \%$ of fiber it was found that the failure occurred due to several factors including the number of the fraction of the weight of the reinforcement is small and the fiber which is clustered (uneven) contained in some parts of the composite which resulted in uneven distribution of load.

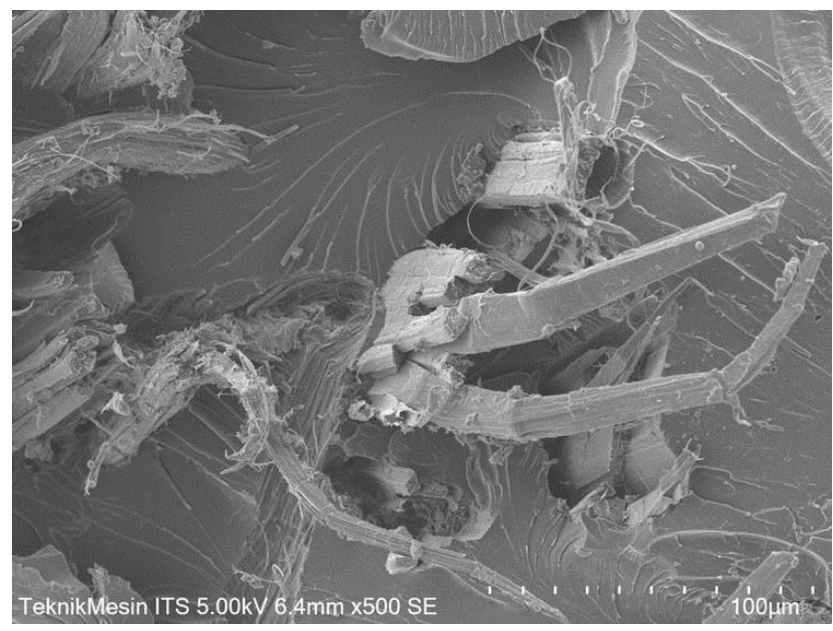

Fig. 7. Nettle composite fracture with $15 \%$ of fiber

Composite $15 \%$ of the fiber shows the number of fibers evenly distributed and tightly bound, but in some parts, there are also fibers and matrices that are not tightly bound, thus allowing the pull-out or release of fiber bonds from the matrix, so that it can affect the ability to withstand the load of material the composite. The existence of porosity in the matrix which causes the material can not accept the maximum load, because the porosity can be one of the factors causing the fault so that the load received cannot be transferred to all parts.

\section{CONCLUSION}

The results obtained are the hardness value of glass fiber composites with a weight fraction of $10 \%, 15 \%, 20 \%$ is 82.4 Shore D, 84.5 Shore D, 86.5 Shore D shows an increase in stable hardness, because the glass fiber factor is commercially strength evenly distributed. The hardness of nettle fiber composites with fractions of $10 \%, 15 \%, 20 \%$ is 81.6 Shore D, 85.0 Shore D and 86.6 Shore D, the hardness value of each composite increases with the addition of fiber weight fraction, but it is unstable due to the uneven strength of the nettle fiber factor. Furthermore, with the right treatment, nettle fiber can replace glass fiber.

\section{REFERENCES}

A. V Singhal et al., "Critical Parameters Affecting Mechanical Behavior of Natural Fiber Reinforced Plastics," J. Nat. Fibers, vol. 13, no. 6, pp. 640-650, 2016.

E. Bodros and C. Baley, "Study of the tensile properties of stinging nettle fibres (Urtica dioica)," Mater. Lett., vol. 62, no. 14, pp. 2143-2145, 2008.

D. Ngakan, K. Putra, T. Gde, T. Nindhia, I. W. Surata, and M. Sucipta, "Potensi bambu swat (gigantochloa verticillata) sebagai material karbon aktif untuk adsorbed natural gas (ANG)," $J$. Energi Dan Manufaktur, vol. 9, no. 2, pp. 174-179, 2017. (in Indonesia)

I. G. P. A. Suryawan, N. P. G. Suardana, I. N. S. Winaya, I. W. B. Suyasa, and I. P. Lokantara, "Study of stinging nettle fibers as a reinforcing of composite materials based on its growing region," in IOP Conference Series: Materials Science and Engineering, 2019.

L. Bacci, S. Baronti, S. Predieri, and N. di Virgilio, "Fiber yield and quality of fiber nettle (Urtica dioica L.) cultivated in Italy," Ind. Crops Prod., vol. 29, no. 2-3, pp. 480-484, 2009.

I. G. P. A. Suryawan, N. Suardana, I. K. Suarsana, I. P. Lokantara, and I. K. J. Lagawa, "Kekuatan Tarik dan Lentur pada Material Komposit Berpenguat Serat Jelatang," J. Energi Dan Manufaktur, vol. 12, no. 1, pp. 7-12, 2019.(in Indonesia) I. G. P. A. Suryawan, N. P. G. Suardana, I. N. S. Winaya, and I. W. B. Suyasa, "A Study on Correlation Between Hardness and Thermal Conductivity of Polymer composites reinforced," Int. $J$. Civ. Eng. Technol., vol. 11, no. 1, pp. 94-104, 2020.

Khalidi, Faten Rashid Al and M. A. Rajab, "Hardness And Wear Resistance Of Composite Materials Supported By Graphite And Silica Particles And Reinforced By Cuffler Fiber," Am. J. Eng. Res., vol. 7, no. 11, pp. 317-322, 2018.

A. Kasim, A.N. Selamat, M.Z. Daud, M.A.M. Yaakob, M.Y. Putra and D. Sivakumar, "Mechanical properties of polypropylene composites reinforced with alkaline treated pineapple leaf fibre from Josapine cultivar," Int. J. Automot. Mech. Eng., vol. 13, no. 1, pp. 3157-3167, 2016.

O. L. Vasdazara, H. Ardhyananta, and S. T. Wicaksono, "Pengaruh Penambahan Serat Cangkang Kelapa Sawit (Palm Kernel Fiber) Terhadap Sifat Mekanik Dan Stabilitas Termal Komposit Epoksi/Serat Cangkang Kelapa Sawit," J. Tek. ITS, vol. 7, no. 1, 2018. (in Indonesia). 